\title{
PENGARUH SENAM OTAK (BRAIN GYM) TERHADAP FUNGSI KOGNITIF PADA LANSIA DI RT 03 RW 01 KELURAHAN TANDES SURABAYA
}

\author{
Yuliati, Nur Hidaayah \\ Fakultas Keperawatan dan Kebidanan \\ Universitas Nahdlatul Ulama Surabaya Jln. SMEA No. 57 Surabaya \\ Email : Nurhid@unusa.ac.id
}

\begin{abstract}
Abstarct : Decline in cognitive function in the elderly is not considered reasonable, and can be inhibited with brain gym activity. The purpose of this study is to investigate the influence of brain exercise on cognitive function in the elderly in RT 03 RW 01 Tandes Village. Design of this study Pre-Experiment with one grop pre post test,the population are from ten of elderly aged 60-74 years. Sampling by simple random sampling, gained 6 people. The independent variable is the gymnastics of the brain and the dependent variable is a function cognitive. The data colledted by using the MMSE tabulation of data editing, coding, processing, celaning, tabulating and analyzed by Wilcoxon Sign Rank with $\alpha=0.05$. The results showed that prior to the brain gym majority (66.7\%) had moderate cognitive impairment after brain gym majority $(66.7 \%)$ are not impaired cognitive function. After the Wilcoxon signed rank test obtained value $\rho=0.014<\alpha=$ 0.05 so that $\mathrm{H}_{0}$ is rejected, it means that there is the influence of brain exercise on cognitive function in the elderly. Conclusions from this research is the brain exercises can improve cognitive function in the elderly in RT 03 RW 01 Tandes village. Brain gym should be applied in Posyandu every 3 times a week as more routine brain exercise in the elderly, then cognitive function will be increased, then can make the decline in function cognitive slowly.
\end{abstract}

Abstrak : Penurunan fungsi kognitif pada lansia bukanlah hal yang dianggap wajar, dan bisa dihambat dengan aktivitas senam otak. Tujuan dari penelitian ini adalah untuk mengetahui pengaruh senam otak terhadap fungsi kognitif pada lansia di RT 03 RW 01 Kelurahan Tandes. Desain penelitian ini pra-Eksperimental dengan one group pra post test, populasinya 10 lansia yang berumur 60-74 tahun. Pengambilan sampel secara simple random sampling, didapat 6 orang. Variabel independen adalah senam otak dan variabel dependen adalah fungsi kognitif. Pengumpulan data dilakukan menggunakan MMSE melalui pengolahan data editing, coding, processing, cleaning, tabulasi dan dianalisis menggunakan Wilcoxon Sign Rank dengan $\alpha=0,05$. Hasil penelitian menunjukkan bahwa sebelum dilakukan senam otak sebagian besar (66,7\%) mengalami gangguan fungsi kognitif sedang dan setelah dilakukan senam otak sebagian besar $(66,7 \%)$ tidak mengalami gangguan fungsi kognitif. Setelah dilakukan uji Wilcoxon signed rank test didapatkan nilai $\rho=0,014<\alpha=0,05$ sehingga $\mathrm{H}_{0}$ ditolak, artinya ada pengaruh senam otak terhadap fungsi kognitif pada lansia. Simpulan dari penelitian ini bahwa senam otak mampu meningkatkan fungsi kognitif pada lansia di RT 03 RW 01 Kelurahan Tandes. Sebaiknya senam otak diterapkan di posyandu setiap 3x seminggu karena semakin rutin 
dilakukan senam otak pada lansia, maka fungsi kognitif akan semakin meningkat, sehingga dapat memperlambat penurunan fungsi kogitif.

Kata kunci : Fungsi Kognitif, Senam Otak, lansia.

\section{PENDAHULUAN}

Lansia yang sering mengalami penurunan kognitif sering dianggap sebagai masalah biasa pada mereka yang memasuki usia lajut. Mitos yang terdapat di masyarakat bila lanjut usia mengalami demensia atau kepikunan, hal itu dianggap wajar dan bila lanjut usia sudah menderita demensia sudah tidak bisa dilakukn apa-apa lagi. Pada kenyataannya demensia stadium ringan dan sedang klien masih bisa ditolong bila terdeteksi secara dini, diberikan nasihat, dan bantuan informasi yang baik dan benar (Nugroho, 2008)

Di Indonesia jumlah penduduk lansia pada tahun 2006 sebesar kurang lebih 19 juta, usia harapan hidup 66,2 tahun, pada tahun 2010 diperkirakan sebesar 23,9 juta $(9,77 \%)$, usia harapan hidupnya 67,4 tahun dan pada tahun 2020 diperkirakan sebesar 28,8 juta $(11,34 \%)$, dengan usia harapan hidup 71,1 tahun. Pada tahun 2012 jumlah penduduk lansia di Jawa Timur sebesar $10,40 \%$ (Pusat Data dan Informasi Kemenkes RI, 2013). Dari sini dapat kita ketahui jumlah lansia dari tahun ke tahun mengalami peningkatan. Menurut organisasi kesehatan dunia (WHO) mencatat penurunan fungsi kognitif lansia diperkirakan 121 juta manusia,dari jumlah itu 5,8 \% lakilaki dan $9,5 \%$ perempuan. Pada Lansia sering terjadi mudah lupa dengan prevalensi $30 \%$ gangguan daya ingat terjadi pada usia 50-59 tahun, 35\%-39\% terjadi pada usia di atas 65 tahun dan $85 \%$ terjadi pada usia di atas 80 tahun. kondisi ini dinamakan Demensia yaitu gangguan kognitif terutama memori disertai gangguan lain misalnya bahasa sehingga mengganggu fungsi sosialnya (Lisnaini, 2012).

Berdasarkan survei awal dengan wawancara 6 lansia pada tanggal 30 januari 2015 di RT 03 RW 01 Kelurahan Tandes didapatkan beberapa data, yaitu: kondisi daya ingat pada lansia yang bergabung di posyandu mangga yang berusia 60-74 tahun mengalami penurunan fungsi kognitif diantaranya terdapat $3(\%)$ orang lansia yang menyatakan sering lupa letak barang yang baru saja digenggamnya, 2 orang (\%) lansia menyatakan sering lupa meletakkan kunci rumah dan selalu menanyakan pada cucunya atau anaknya, 1 orang lansia mengatakan belum melakukan sarapan pagi padahal sudah melakukannya.

Otak sangat mudah rusak akibat radikal bebas, karena bahan kimia berbahaya ini mudah terserap oleh lemak sedangkan sebagian besar struktur otak adalah lemak sehingga para penelti sepakat bahwa radikal bebas merupakan penyebab tanda-tanda penuaan. Penuaan pada lansia menyebabkan terjadinya perubahan anatomi dan biokimiawi di susunan saraf pusat yaitu berat otak akan menurun sebanyak sekitar $10 \%$ pada penuaan antara umur 30-70 tahun. Pada proses penuaan otak, terjadi penurunan jumlah neuron secara bertahap yang meliputi area girus temporal superior (merupakan area yang paling cepat kehilangan neuron), girus presentralis dan area striata. Secara patologis penurunan jumlah neuron kolinergik akan menyebabkan berkurangnya neurotransmiter asetikolin sehingga menimbulkan gangguan kognitif dan perilaku (Paretta, L. 2005).

Beragam pencegahan untuk menghambat penurunan kognitif mulai dari terapi farmakologis dengan menggunakan obat-obatan sampai terapi non farmakologis seperti 3 kegiatan 
aktivitas stimulasi otak yaitu aktivitas fisik (senam otak), aktivitas mental dan aktivitas sosial. Terapi non farmakologis perlu diterapkan untuk menunda kemunduran kognitif dengan menerapkan perilaku sehat dan melakukan stimulasi otak sedini mungkin untuk melatih kemampuan otak bekerja. Oleh karena itu perlu mengantisipasi dan meminimalisir perubahan yang terjadi pada lansia tersebut. Salah satu stimulasi otak yang dilakukan untuk meningkatkan fungsi kognitif lansia yaitu dengan aktivitas fisik yaitu olahraga senam otak (brain gym) untuk mempertahankan kemampuan yang ada dengan terus memberikan stimulasi pada otak (Markam, 2005).

Senam otak atau lebih dikenal dengan Brain Gym adalah gerakan-gerakan ringan dengan permainan melalui olah tangan dan kaki dapat memberikan rangsangan atau stimulus pada otak. Gerakan yang menghasilkan stimulus itulah yang dapat membantu meningkatkan fungsi kognitif dan menunda penuaan dini dalam arti menunda pikun atau perasaan kesepian yang biasanya menghantui para manula (Gunadi, 2009)

Berdasarkan penelitian yang dilakukan Ranita et al (2012) brain gym yang dilakukan selama dua minggu sangat efektif dalam menurunkan stress pada anak. Menurut penelitian lain dengan judul senam vitalitas otak dapat meningkatkan fungsi kognitif pada usia dewasa muda terdapat peningkatan fungsi kognitif setelah dilakukan senam otak sebanyak tiga kali selama tiga minggu dengan nilai $p<0,05$ (Lisnaini, 2012). Berdasarkan latar belakang diatas peneliti tertarik untuk menelliti tentang Pengaruh Senam Otak (Brain Gym) Terhadap Fungsi Kognitif Pada Lansia di RT 03 RW 01 KelurahanTandes Surabaya.

\section{METODE}

Dalam penelitian ini jenis penelitian yang digunakann adalah penelitian kuantitatif dengan desain Pra Eksperimental dengan pendekatan one group pra post test. Populasi penelitian ini adalah lansia yang berumur 60-74 tahun sebesar 10 responden di RT 03 RW 01 Kelurahan Tandes. Pengambilan sampel secara simple random samplingdidapatkan 6 orang. Waktu penelitian adalah mulai bulan april sampai mei 2015. Analisa data dengan SPSS 18 menggunakan uji Wilcoxon Sign Rank dengan $\alpha=0,05$.

\section{HASIL}

Hasil penelitian menunjukkan dari 6 responden sebagian besar (96,7\%) berumur 60-69 tahun sebanyak 4 orang. Berdasarkan jenis kelamin hampir seluruhnya $(83,8 \%)$ berjenis kelamin perempuan sebanyak 5 orang. Berdasarkan pendidikan sebagian besar $(66,7 \%)$ memiliki pendidikan tingkat dasar.

Distribusi pekerjaan menunjukkan bahwa 3 orang $(50,0 \%)$ memiliki pekerjaaan sebagai ibu rumah tangga.

Distribusi fungsi kognitif berdasarkan kuesioner MMSE sebelum dilakukan senam otak dapat dilihat pada tabel berikut.

Tabel 1 Distribusi frekuensi Fungsi Kognitif berdasarkan kuesioner MMSE sebelum dilakukan senam otak di RT 03 RW 01 Kelurahan Tandes Surabaya

\begin{tabular}{lcc}
\hline Fungsi Kognitif & Frekuensi & $\begin{array}{c}\text { Persentase } \\
(\%)\end{array}$ \\
\hline $\begin{array}{l}\text { Tidak ada } \\
\text { gangguan (24-30) }\end{array}$ & 0 & 0 \\
$\begin{array}{l}\text { Gangguan kognitif } \\
\text { sedang (18-23) }\end{array}$ & 4 & 66.7 \\
$\begin{array}{l}\text { Gangguan kognitif } \\
\text { berat (0-17) }\end{array}$ & 2 & 33.3 \\
\hline \multicolumn{1}{c}{ Jumlah } & 6 & 100,0 \\
\hline
\end{tabular}

Tabel 1 menunjukkan distribusi fungsi kognitif berdasarkan kuesioner MMSE sebelum dilakukan senam otak bahwa dari 6 responden sebagian besar $(66,7 \%)$ mengalami gangguan fungsi kognitif sedang.

Tabel 2 Distribusi frekuensi Fungsi Kognitif berdasarkan kuesioner MMSE sesudah dilakukan senam otak di RT 03 RW 01 Kelurahan Tandes Surabaya. 


\begin{tabular}{lcc}
\hline Fungsi Kognitif & Frekuensi & $\begin{array}{c}\text { Persent } \\
\text { ase }(\%)\end{array}$ \\
\hline $\begin{array}{l}\text { Tidak ada gangguan } \\
(24-30)\end{array}$ & 0 & 0 \\
$\begin{array}{l}\text { Gangguan kognitif } \\
\text { sedang (18-23) }\end{array}$ & 4 & 66.7 \\
$\begin{array}{l}\text { Gangguan kognitif } \\
\text { berat (0-17) }\end{array}$ & 2 & 33.3 \\
\hline \multicolumn{1}{c}{ Jumlah } & 6 & 1000 \\
\hline
\end{tabular}

Tabel 2 menunjukkan distribusi fungsi kognitif berdasarkan kuesioner MMSE sesudah dilakukan senam otak pada 6 responden sebagian besar $(66,7 \%)$ tidak mengalami gangguan kognitif sesudah dilakukan senam otak.

Tabel 3 Distribusi perbedaan fungsi kognitif sebelum dan sesudah dilakukan senam otak pada lansia di RT 03 RW 01 Kelurahan Tandes Surabaya.

\begin{tabular}{|c|c|c|c|c|}
\hline \multirow{3}{*}{$\begin{array}{c}\text { Fungsi } \\
\text { Kognitif }\end{array}$} & \multicolumn{4}{|c|}{ Senam Otak } \\
\hline & \multicolumn{2}{|c|}{ Pre } & \multicolumn{2}{|c|}{ Post } \\
\hline & $\mathrm{N}$ & $\%$ & $\mathrm{~N}$ & $\%$ \\
\hline $\begin{array}{l}\text { Tidak ada } \\
\text { gangguan } \\
\text { kogntif }\end{array}$ & 0 & 0 & 4 & 66.7 \\
\hline $\begin{array}{l}\text { Gangguan } \\
\text { kognitif } \\
\text { sedang }\end{array}$ & 4 & 66.7 & 2 & 33.7 \\
\hline $\begin{array}{l}\text { Gangguan } \\
\text { kognitif berat }\end{array}$ & 2 & 33.3 & 0 & 0 \\
\hline Jumlah & 6 & 100 & 6 & 100 \\
\hline $\begin{array}{c}\mathrm{P} \text { value } \\
\text { Wilcoxon }\end{array}$ & \multicolumn{4}{|c|}{0,014} \\
\hline
\end{tabular}

Tabel 3 menunjukkan bahwa fungsi kognitif sebelum dilakukan senam otak (pre-test) sebagian besar responden $(66,7 \%)$ menyatakan mengalami gangguan fungsi kognitif sedang (17-23) dan sesudah diberikan senam otak (post-test) sebagian besar responden $(66,7 \%)$ menyatakan tidak mengalami gangguan fungsi kognitif (24-30).

Berdasarkan hasil uji statistik Wilcoxon sign rank test dengan menggunakan SPSS for Windows dengan tingkat kemaknaan $\alpha=0,05$ didapatkan $\rho$ $=0,014$, berarti $\rho<\alpha$ maka $\mathrm{H}_{0}$ ditolak artinya ada pengaruh senam otak terhadap fungsi kognitif pada lansia di RT 03 RW 01 Kelurahan Tandes Surabaya.

\section{PEMBAHASAN}

1. Fungsi Kognitif Sebelum (Pre Test) Diberiakn Senam Otak

Hasil dari penelitian menunjukkan bahwa fungsi kognitif sebelum diberikan senam otak sebagian besar $(66,7 \%)$ memiliki gangguan fungsi kognitif sedang, dan hampir setengahnya (33,3\%) mengalami gangguan fungsi kognitif berat. Dari hasil persentase tes kuesioner MMSE (pretest) didapatkan bahwa responden paling banyak mengalami kemunduran daya ingat misalnya menyebutkan nama benda yang telah disebutkan sebelumnya. Menurtut Nugroho (2008) ciri gangguan fungsi kogntif sedang (awal) diantaranya kesulitan dalam berbahasa, mengalami kemunduran daya ingat, disorientasi waktu dan tempat dan sangat mudah lupa, terutama untuk peristiwa yang baru dari nama orang.

Berdasarkan tes kuesioner MMSE (pre test) didapatkan lansia banyak mengalami kemunduran daya ingat. Pelupa merupakan tanda awal gangguan fungsi kognitif ringan, pelupa dalam hal ini melebihi pelupa yang kadang-kadang terjadi dan normal yang dialami sebagai bagian proses penuaan.

Selain itu usia juga dapat mempengaruhi fungsi kognitif. Berdasarkan hasil penelitian dari 6 responden sebagian besar (66,7\%) berumur 60-69 tahun. Pada lanjut usia akan sering muncul keluhan semakin pelupa. Kondisi semakin menjadi pelupa ini selain akibat proses penuaan sel-sel otak, juga dapat disebabkan karena berkurangnya pasokan gizi melalui makanan untuk otak (Program Pendidikan Dokter Spesialis Neurologis, 2008) menyatakan bahwa usia mempengaruhi kemampuan kognitif seseorang dimana semakin bertambahnya usia akan menimbulkan variatif pada kemampuan fungsi kognitifnya pada setiap individu tidak sama. 
Jenis kelamin juga mempengaruhi fungsi kognitif. Sesuai hasil penelitian dari 6 responden hampir seluruhnya $(83,3 \%)$ responden terjadi pada perempuan, karena perempuan yang lebih beresiko mengalami penurunan kogniti. Menurut Zulsita A. (2010) yang menyatakan wanita tampaknya lebih beresiko mengalami penurunan kognitif dari pada laki-laki. Hal ini disebabkan adanya peranan level hormon seks endogen dalam perubahan fungsi kognitif. Reseptor estrogen telah ditemukan dalam area otak yang berperan dalam fungsi belajar dan memori, seperti hipokampus. Rendahnya level estradiol dalam tubuh telah dikaitkan dengan penurunan fungsi kognitif umum dan memori verbal. Estradiol diperkirakan bersifat neuroprotektif dan dapat membatasi kerusakan akibat stress oksidatif serta terlihat sebagai protektor sel saraf dari toksisitas amiloid pada pasien Alzheimer (Zulsita A, 2010)

Tingkat pendidikan juga mempengaruhi fungsi kognitif. Sesuai hasil penelitian dari 6 responden sebagian besar $(66,7 \%)$ responden memiliki tingkat pendidikan dasar (SD). Pendidikan yang rendah akan menjadikan seseorang tidak menggunakan otak untuk berpikir secara rutin, dan otak tidak terlatih sehingga daya ingat tidak dapat dijaga. Semakin tinggi tingkat pendidikan lansia maka akan semakin baik fungsi kognitifnya. Tingkat pendidikan yang rendah berhubungan dengan penurunan fungsi kognitif yang dapat terjadi lebih cepat dibandingkan dengan tingkat pendidikan yang tinggi. Satu teori menjelaskan tentang synaptic reserve hypothesis, dimana orang yang berpendidikan tinggi mempunyai lebih banyak synaps di otak dibanding orang yang berpendidikan rendah. Ketika synap tersebut rusak karena ada proses penyakit Alzheimer maka synap yang lain akan menggantikan tempat yang rusak tadi. Teori ini berhubungan dengan cognitive reserve hypothesis dimana orang yang beredukasi memiliki lebih banyak sinaps pada otak dan mampu melakukan mengkompensasi dengan baik terhadap hilangnya suatu kemampuan dengan menggunakan strategi alternative pada tes yang didapati selama pelatihan selama pendidikan, dengan demikian dapat diasumsikan orang yang berpendidikan tinggi menurun fleksibilitas ini dalam testtaking strategy (Dash, VillemarettePittman, 2005).

Pekerjaan juga mempengaruhi fungsi kognitif. Sesuai dengan penelitian, pada dari 6 responden setengahnya $(50,0 \%)$ responden bekerja sebagai ibu rumah tangga (petani). Menurut Modul Neurobehavior (2008) Pekerjaan dapat mempercepat proses menua yaitu pada pekerja keras/over working, seperti pada buruh kasar atau petani. Pekerjaan orang dapat mempengaruhi fungsi kognitifnya, dimana pekerjaan yang terus-menerus melatih kapasitas otak dapat membantu mencegah terjadinya penurunan fungsi kognitif dan mencegah demensia.

Problem yang dihadapi orang berusia lanjut adalah berkurangnya bobot otak, dimana pada manusia dengan usia memasuki 50 tahun maka terjadi penyusutan otak dengan berat otak berkurangnya menjadi 1,2 kilogram dan $10 \%$ dari kurang lebih 100 miliar sel otak terdegenerasi (Setiabudi, 2012).

2. Fungsi Kognitif Setelah (Post Test) Diberiakan Senam Otak

Fungsi kognitif pada lansia di RT 03 RW 01 Kelurahan Tandes Surabaya sesudah diberikan senam otak mengalami peningkatan. Berdasarkan hasil penelitian bahwa sesudah diberikan senam otak dari 6 resonden sebagian besar $(66,7 \%)$ responden tidak ada gangguan fungsi kognitif dan hampir setengahnya $(33,3 \%)$ mengalami gangguan fungsi kognitif sedang. Penurunan jumlah persentase responden dengan gangguan fungsi kognitif sedang dan peningkatan fungsi kognitif dalam batas tidak ada gangguan kognitif (normal) membuktikan bahwa apabila senam otak dilakukan secara rutin minimal 1 hari 1 kali melakukan senam otak dapat melawan proses penuaan pada 
otak dan dapat menghambat proses penurunan fungsi kognitif. Senam otak dapat meningkatkan daya ingat responden, hal ini terbukti dengan peningkatan persentase tes ingatan pada tes MMSE.

Peningkatan fungsi kognitif ini setelah responden diberikan senam otak dengan frekuensi 1 kali sehari selama satu bulan. Senam otak ini dilakukan sesuai dengan SPO senam otak yang dilakukan selama 5 -10 menit. Senam otak dilakukan door to door setiap pagi pukul 06.30 WIB sampai selesai. Berdasarkan hasil penelitian di atas diketahui terdapat peningkatan kognitif pada lansia setelah dilakukan senam otak. Sehingga dapat disimpulkan bahwa senam otak yang dilakukan secara rutin dapat meningkatkan fungsi kognitif pada lansia yang didukung dengan teori Markam (2005) menyatakan bahwa pemeliharaan otak secara fungsional dapat dilakukan dengan berbagai proses belajar, di antaranya dengan belajar gerak, belajar mengingat, belajar merasakan dan sebagainya. Semua proses belajar tersebut akan selalu merangsang pusat-pusat otak (brain learning stimulation), yang $\mathrm{di}$ dalamnya terdapat pusat-pusat yang mengurus berbagai fungsi tubuh.

Hasil peneltian menunjukkan bahwa senam otak mampu meningkatkan fungsi kognitif pada lansia dibandingkan sebelum diberikan senam otak. Melalui gerakangerakan permainan olah tangan dan kaki yang mengahasilkan stimulus itulah yang dapat meningkatkan fungsi kognitif. Menurut Dennison (2009) bahwa senam otak (brain gym) adalah serangkaian gerak sederhana yang menyenangkan bisa digunakan dari berbagai usia dan gerakangerakan pada brain gym dapat memberikan rangsangan atau stimulus pada otak. Gerakan yang menghasilkan stimulus itulah yang dapat membantu meningkatkan fungsi kognitif dan menunda penuaan dini dalam arti menunda pikun atau perasaan kesepian yang biasanya menghantui para manula (Gunadi, 2009).

Berdasarkan hasil tabel 2 menunjukkan bahwa senam otak terbukti bisa meningkatkan fungsi kognitif pada lansia. Terapi non farmakologis untuk menghambat penurunan fungsi kognitif inilah yang perlu dikembangkan. Menurut Nugroho (2008) menyebutkan untuk menghambat penurunan fungsi kognitif ada 2 penatalaksanaan yaitu penatalaksanaan farmakogis dengan menggunakan obat-obatan antara lain: anti oksidan , obat anti inflamasi, obat penghambat asetikolin esterase dan panatalaksanaan non farmologis dengan melakukan 3 kegiatan stimulasi otak diantaranya aktivitas fisik (senam otak), aktivitas sosial (pengajian rutin, mengkuti arisan PKK), aktivitas mental (permainan puzzle, membuat kerajinan tangan, diskusi, dan bernyanyi).

3. Pengaruh Senam Otak Terhadap Fungsi Kognitif

Berdasarkan hasil penelitian pada tabel 3 menunjukkan bahwa dari 6 responden sebelum diberikan senam otak sebagian besar $(66,7 \%)$ mengalami gangguan fungsi kognitif sedang sedangkan sesudah diberikan senam otak sebagian besar $(66,7 \%)$ tidak mengalami gangguan fungsi kognitif. Hal ini berarti terdapat pengaruh senam otak terhadap fungsi kogntif. Berdasarakan uji Wilcoxon Sign Rank didapatkan nilai $\rho$ adalah 0,014 dan nilai $\alpha=0,05$, berarti $\rho<\alpha$ maka $\mathrm{H}_{0}$ ditolak artinya ada pengaruh senam otak terhadap fungsi kognitif pada lansia di RT 03 RW 01 Kelurahan Tandes Surabaya. Pengaruh dari senam otak yang dilakukan secara rutin (1 kali sehari selama 1 bulan) ini membuktikan bahwa fungsi kognitif dapat di hambat salah satunya dengan terapi non farmakologis seperti senam otak yang dilakukan secara rutin. Latihan senam otak ini membuka bagian-bagian otak yang sebelumnya tertutup atau terhambat. Disamping itu, senam otak tidak hanya memperlancar aliran darah dan oksigen ke otak juga merangsang kedua belah otak untuk bekerja sehingga didapat keseimbangan aktivitas kedua belahan otak secara bersamaan (Denisson, P.E. dan Gail E.D, 2009). 
Porsi latihan yang tepat adalah sekitar 10-15 menit, sebanyak 2-3 kali dalam sehari hasilnya bisa segera diketahui setelah melakukan latihan secara teratur selama 2 minggu berturut-turut. Latihan yang dilakukan secara teratur akan memperlihatkan hasil yang optimal (Andri, 2013).

Hasil penelitian pada tabel 3 menunjukkan bahwa dari 6 responden seluruhnya (100\%) mengalami peningkatan fungsi kognitif saat posttest. Empat orang adalah orang yang mengalami gangguan fungsi kognitif sedang pada saat pretest menjadi tidak mengalami gangguan kognitif (normal) pada saat posttest dan dua orang yang mengalami gangguan fungsi kognitif berat pada saat pretest menjadi mengalami gangguan fungsi kognitif sedang pada saat postest. Peningkatan fungsi kognitif dapat disebabkan karena responden rutin melakukan senam otak dan menggunakan otak secara terus menerus dan di istirahatkan dengan tidur, dan melakukan kegiatan seperti membaca, menulis, mendengarkan berita, cerita dan megisi teka teki silang (TTS). Setelah responden melakukan senam otak selama 1 bulan secara rutin setiap hari mengahasilkan perubahan nilai tes MMSE ke arah yang positif (mendekati menjadi normal). Nugroho (2008) menyatakan apabila aktivitas fisik seperti senam otak dilakukan secara rutin dapat menghambat penurunan fungsi kognitif. Gerakan sederhana dalam senam otak yang mengahasilkan stimulus itulah yang dapat meningkatkan daya ingat dan menunda penuaan dini dalam arti menunda pikun atau perasaan kesepian yang biasanya menghantui para manula.

Sebuah studi telah menunjukkan bahwa jika kita melakukan aktivitas fisik juga dapat langsung menstimulasi otak, sehingga saat kita melakukan olahraga teratur dapat meningkatkan protein di otak yang disebut Brain Derived Neurotrophic Factor (BDNF). Protein BDNF ini berperan penting menjaga sel saraf tetap bugar dan sehat. Telah banyak penelitian mengenai peranan BDNF terhadap fungsi memori. Kadar BDNF yang rendah dapat menyebabkan penyakit kepikunan. Berbagai fakta menunjukkan olahraga dapat meningkatkan kadar BDNF. Fakta inilah yang dapat menjelaskan bahwa lansia yang banyak melakukan aktivitas fisik yang menyenangkan mempunyai fungsi kognitif yang lebih baik.

\section{KESIMPULAN}

1. Lansia sebelum diberikan senam otak sebagian besar mengalami gangguan kognitif sedang di RT 03 RW 01 Kelurahan Tandes Surabaya.

2. Lansia sesudah diberikan senam otak sebagian besar tidak mengalami gangguan kognitif di RT 03 RT 01 Kelurahan Tandes Surabaya.

3. Ada pengaruh senam otak terhadap fungsi kognitif pada lansia yang yang diberikan senam otak pada lansia di RT 03 RW 01 Kelurahan Tandes Surabaya.

\section{DAFTAR PUSTAKA}

Andri.(2013). Memaksimalka Otak Melalui Senam Otak (Brain Gym). Yogyakarta, TernovaBooks.

Dash, Villemarette-Pittman. (2005). Alzheimer's Disease. https://www.amazon.com/Alzheim ers-Disease-Villemarette-PitmanVillemarette-PittmanPaperback/dp/B014N7KRZI. diakses tanggal 13 Februari 2015.

Dennison, Paul. E dan Gail E. Dennison.(2009). Brain Gyam and me. Jakarta, Gramedia Pustaka Utama.

Gunadi, T.(2009). 24 Gerakan Meningkatkan Kecerdasan Anak. Jakarta, Penebar Plus

Lisnaini.(2012). Fungsi Kognitif Usia Dewasa Senam Vitalisasi Otak Dapat Meningkatkan Muda. Skripsi. Jakarta, Fisioterapi Universitas Kristen Indonesia.

Markam, S. (2005). Latihan Vitalisasi Otak Indonesia (Senam untuk 
Kebugaran Fisik dan Otak). Jakarta. Grasindo.

Program Pendidikan Dokter Spesialis Neurologis. (2008). Modul Neurobehavior. Kolegium Neurologi, Indonesia.

Nugroho, W.(2008). Keperawatan Gerontik dan Geriatrik, Edisi 3. Jakarta, EGC.

Parreta, L.(2005). Makanan untuk Otak. Panduan Penting untuk Meningkatkan Kemampuan Otak Anda. Jakarta. Erlangga.

Pusat Data dan Informasi Kemenkes RI (2013). Gambara Kesehatan Lanjut Usia di Indonesia. www.depkes.go.id/download.php?fi le $=$ download/pusdatin/...lansia.pdf. Diakses tanggal 10 Januari 2015.

Zulsita.(2010). Pengaruh Senam Otak terhadap Peningkatan Daya Ingat Lansia di Panti Werdha Karya Kasih Mongonsidi. Skripsi. Medan, Fakultas Keperawatan Universits Sumatera Utara. Skripsi. 